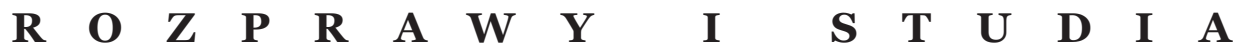

„Studia Archiwalne”, t. 7, 2020

ISSN $1734-7513$

Marcin Pytel

(Lublin)

\section{Klauzula pertynencyjna w dokumentach książęcych w Wielkopolsce do 1296 r.*}

ZARYS TREŚci: Artykuł jest poświęcony klauzuli pertynencyjnej na dokumentach z terenów Wielkopolski XII-XIII w. Przedstawiono w nim schematy redakcyjne tejże klauzuli oraz chronologię jej występowania na analizowanych dokumentach. Przeprowadzona analiza prowadzi do wniosku, że klauzula pertynencyjna była tak samo sformalizowana jak inne części średniowiecznego dokumentu.

SŁowA KLUCzowe: dyplomatyka, klauzula pertynencyjna, formuła, badanie dyktatu, kancelarie wielkopolskie XIII w.

AвSTRACт: The article is devoted to the proprietary clause in the documents from the territory of Greater Poland in $12^{\text {th }}-13^{\text {th }} \mathrm{c}$. The author presented the editorial patterns of this clause and the chronology of its appearance on the analyzed documents. The conducted analysis leads to the conclusion that the proprietary clause was formalized in the same way as other parts of the medieval document.

KEYWORDS: diplomatic, proprietary clause, formula, study of contents, Great Poland offices in the $13^{\text {th }}$ century

Badania nad dyktatem dokumentów należą do klasycznego, utartego kanonu badań dyplomatycznych. Szczególnie badacze rozlicznych kancelarii stosowali w swych rozważaniach obok analizy duktu analizę dyktatu ${ }^{1}$ Koncentrowano

* Moje rozważania obejmą również dokumenty Przemysła II jako króla Polski.

${ }^{1}$ Por. literaturę dotyczącą kancelarii książęcych, np. wielkopolskich, jak w przypisie nr 17. 
się głównie na formułach protokołu i eschatokołu, pomijając prawie zupełnie kontekst dokumentów, a zwłaszcza dyspozycję ${ }^{2}$. Wynikało to z przekonania, że dyspozycja, zawierająca postanowienia prawne dokumentu, nie mogła być zredagowana według przyjętych schematów redakcyjnych. Jednak wydaje się, że właśnie formuły dyspozycji, po pierwsze, dają się analizować klasycznymi metodami przynależności kancelaryjnej dokumentów, a po drugie, w konsekwencji - są również sformalizowanymi elementami dokumentu. $\mathrm{W}$ artykule tym staram się pokazać, na przykładzie klauzuli pertynencyjnej, że daje się ją analizować metodami analizy dyktatu i stanowi ona raczej element retoryczny - figurę enumeratio ${ }^{4}$ niż formułę prawną.

Klauzula pertynencyjna $a^{5}$ jest jedynym elementem dyspozycji, którą wymieniają polskie podręczniki nauk pomocniczych historii ${ }^{6}$. Według definicji Józefa Szymańskiego klauzula pertynencyjna wymienia części składowe darowizny ${ }^{7}$. Jako pierwsi jednakże zwrócili na nią uwagę historycy prawa, choć bez uświadamiania sobie jej formalnego charakteru. Tak np. Romuald Hube wskazał na podział własności jako „rzecz główna i jej przynależności”, tj. z łaciny pertinentiae bądź attinentiae ${ }^{8}$. Określił również majątek ziemski jako siedzibę i jej przynależności, czyli łączące się z nią części, prawnie jej przysługujące i razem $\mathrm{z}$ nią tworzące w oznaczonych granicach jedną całość. Posługując się przykładami zaczerpniętymi z XIII-wiecznych źródeł, wskazał, iż do przynależności majątku ziemskiego należały: wszystkie pola uprawne i nieuprawne, zarośla, las i wszystko, co jest zawarte w granicach dziedziny i z nią jest połączone oraz

${ }^{2}$ Por. jak w przypisie nr 16.

${ }^{3}$ Autor niniejszego artykułu przygotowuje osobny tekst na temat formuł dyspozycji na dokumentach książąt wielkopolskich, w którym m.in. ma zamiar analizować w ten sposób również inne formuły kontekstu.

${ }^{4}$ Zob. np. Z. Samolewicz, Składnia łacińska, Kraków 2006, s. 242 czy fundamentalne opracowanie: H. Lausberg, Retoryka literacka. Podstawy wiedzy o literaturze, Bydgoszcz 2002, s. 376-380. Figury tej nie odnajduje jednak na badanych przez siebie dokumentach H. Fichtenau, Rhetorische Elemente in der ottonisch-salischen Herrscherurkunde, ,, Mitteilungen des Instituts für österreichischer Geschichtsforschung", t. 68, 1960, s. 39-62.

${ }^{5}$ Formułę od klauzuli odróżniam tu za Vocabulaire international de diplomatique, ed. Ma. Carces Orti, Valencia 1994, s. 54 i 58.

${ }^{6}$ W. Semkowicz, Encyklopedia nauk pomocniczych historii, Kraków 1999, s. 61; J. Szymański, Nauki pomocnicze historii, Warszawa 2001, s. 449.

7 J. Szymański, op. cit., s. 449.

${ }^{8}$ R. Hube, Prawo polskie $w$ wieku trzynastym, [w:] idem, Pisma zbiorowe, t. 2, Warszawa 1905, s. $414-417$. 
wszelkiego rodzaju wody, błota, karczmy i młyny ${ }^{9}$. Badacz ten odnotował także, iż w źródłach z XIII w. występuje wszędzie podobna terminologia przynależności i użytków. Dla R. Hubego wszystkie wymieniane przynależności stanowiły realnie przekazywane części składowe nieruchomości.

Ponad pół wieku później Stanisław Russocki przyjął dla średniowiecznego Mazowsza definicję majątku ziemskiego za R. Hubem, wyróżniając tym samym $\mathrm{z}$ formularza dokumentu, niejako nieświadomie, klauzulę pertynencyjng ${ }^{10}$. Podobnie jak poprzednik, wymieniane w dyplomach części składowe nieruchomości zdawał się traktować serio.

Zupełnie inne stanowisko zajął historyk Stanisław Kuraś, wypowiadając się $\mathrm{w}$ zaledwie kilku uwagach na temat klauzuli pertynencyjnej przy okazji szerszych rozważań prowadzonych nad formularzem przywilejów prawa niemieckiego w Małopolsce XIV-XV w. ${ }^{11}$ Stwierdził obecność klauzuli pertynencyjnej na dokumentach polskich od drugiej połowy XIII w. Historyk ten, przeciwnie do swych poprzedników, uznał, że dokumenty dotyczące obrotu nieruchomościami rozbudowywano, „ile się dało”, wymieniając, co w danej posiadłości znajdowało się w istocie oraz co mogło się weń znajdować. S. Kuraś wskazał również na przykłady trudności przy rozbiorze klauzuli pertynencyjnej. Zdaniem tego badacza, o ile do zaakceptowania jest jeszcze przykładowe sformułowanie dokumentu przedstawiające nadanie wsi cum molendino, tabernis, silvis, aquis, o tyle wymienienie tych samych przynależności w wypadku jednego łanu musi budzić, co najmniej, wątpliwości. S. Kuraś posłużył się przy tym konkretnym przykładem dokumentu z 1400 r., zawierającego opis transakcji zamiany wsi Gnatowice na Kotowice, który wystawili: biskup krakowski Piotr Wysz i opat klasztoru w Tyńcu Mścisław.W dokumencie powiedziano, że klasztor benedyktynek w Staniątkach odstąpił Janowi Tęczyńskiemu część wsi Gnatowice, która leżała wśród: lasów, borów, gajów sosnowych, świerkowych, dębowych, olszynowych i jeżynowych, rzek, potoków, jezior i bagien, przy czym opisy obu wsi stanowiących przedmiot transakcji zawierają taki sam wykaz przynależności. Posługując się informacjami zaczerpniętymi z Długosza oraz XVIII-wiecznej mapy, S. Kuraś stwierdził, iż obie wsi znajdowały się na terenie gęstego osadnictwa: Kotowice w okolicy zupełnie bezwodnej, zaś w pobliżu Gnatowic znajdował się jedynie tylko jeden potok.

\footnotetext{
${ }^{9}$ Wskazując jednocześnie, że przykładowo młyny same mogły posiadać własne przynależności.

${ }^{10}$ S. Russocki, Formy władania ziemia w prawie ziemskim Mazowsza (koniec XIV-połowa XVI wieku), Warszawa 1961, s. 34-36.

11 S. Kuraś, Przywileje prawa niemieckiego miast i wsi małopolskich XIV-XV wieku, Warszawa 1971, s. 61-63.
} 
Ostatni, jak dotąd, głos na gruncie polskim odnoszący się do klauzuli pertynencyjnej należy do Agnieszki Gut i zawiera się w pracy poświęconej formularzowi dokumentów książąt zachodniopomorskich ${ }^{12}$. A. Gut zaliczyła klauzule pertynencyjna do grupy formuł dyplomatycznych dyspozycji, tj. nienadających dokumentowi wartości prawnej, będących jednocześnie najbardziej zeschematyzowanymi spośród formuł dyspozycyjnych. Autorka stwierdziła, iż na badanych dokumentach nie daje się wskazać konkretnych redaktorów, którzy używaliby tej samej kolejności wymienianych użytków w klauzuli pertynencyjnej ${ }^{13}$, a sama klauzula pertynencyjna obecna była na dokumentach książąt zachodniopomorskich już w XII stuleciu.

A. Gut całą swą uwagę skupiła na badaniu wiarygodności klauzuli pertynencyjnej, zastanawiając się, które użytki wymieniane w klauzuli były rzeczywiście przekazywane odbiorcom dokumentów, a które stanowiły jedynie ozdobnik formularzowy. W konsekwencji swych rozważań uznała za wiarygodne nadania opatrzone najbardziej typowym katalogiem użytków, zawartym w klauzuli pertynencyjnej, stanowiącym: pola, łąki, lasy oraz wody, ze względu na powszechność ich występowania w terenie. Za wiarygodne nadania A. Gut przyjęła także nadania winnic, przede wszystkim dlatego, że występowały one niezwykle rzadko w przebadanych przez nią dokumentach. Nadaniu winnic nie stały na przeszkodzie również warunki klimatyczne panujące wówczas na Pomorzu, gdyż granica terenów ze średnią temperatur rocznych $+7,2{ }^{\circ} \mathrm{C}$, optymalną dla uprawy winorośli, występowała w średniowiecznej Polsce na północ od Noteci. Na podobnej podstawie A. Gut uznała za w pełni możliwe nadania chmielników, urządzeń do łowienia ryb oraz grobli, pojawiających się w klauzuli pertynencyjnej dokumentów książąt zachodniopomorskich wyjątkowo rzadko. Natomiast fikcję, według tej autorki, stanowiły nadania salin, gdyż na dokumentach przeznaczonych dla ośrodków położonych w rejonach występowania salin na Pomorzu Zachodnim, w pobliżu Kołobrzegu i Gryfii, nie wymieniano ich w klauzuli. Nadaniom żelaza, złota i srebra A. Gut również odmówiła jakiejkolwiek realności, ze względu na brak występowania tychże metali na badanym obszarze. Podobnie nierealne okazały

12 A. Gut, Formularz dokumentów książąt zachodniopomorskich do połowy XIV wieku, Szczecin 2002, s. $157-174$.

${ }^{13}$ Jednakże w trakcie swoich dalszych rozważań nieraz zdołała przypisać konkretne sformułowania klauzuli pertynencyjnej poszczególnym pisarzom kancelarii książęcych, patrz s. 167-170, ale także wyróżniając klauzulę, stanowiącą, wedle autorki, uzupełnienie klauzuli pertynencyjnej, wskazała na pisarzy kancelarii książęcej, Rodulfa oraz Bernarda - na zredagowanych przez nich dyplomach występowała owa klauzula, zob. ibidem, s. 173. 
się nadania młynów, gajów, bagien, stawów, rzek, krzewów, torfowisk, drewna oraz ogólnie określonych użytków, jako usuagiis, gdyż występowały one bądź na dokumentach o formularzu typowo cysterskim, bądź na dyplomach, których dyktat łatwo dało się przypisać pisarzom kancelarii książęcych.

A. Gut wyróżniła ponadto formułę, powiązaną z klauzulą pertynencyjna, w której wymieniano dochody, prawa i różne korzyści przekazywane odbiorcy dokumentu. Klauzula ta, nienazwana w żaden sposób przez autorkę, pojawiła się na dokumentach książąt zachodniopomorskich w latach 60. XIII w. Wyróżnioną klauzulę A. Gut skłonna była uznać za retoryczny ozdobnik, gdyż ściśle wiązała się z klauzulą pertynencyjną. Występujące w niej zwroty, charakterystyczne dla formularza immunitetowego, bywały wystylizowane zbyt ogólnie, aby można było dopatrywać się tu rzeczywistych zwolnień ${ }^{14}$.

Podsumowując stan badań nad klauzulą pertynencyjną, można wskazać ponadto, iż rozmiary owej klauzuli służyły czasem historykom do określania autentyczności bądź fałszerstwa średniowiecznych dokumentów ${ }^{15}$.

${ }^{14}$ Zob. w tej sprawie niedrukowane fragmenty mojej rozprawy doktorskiej pt. Formuły dyspozycji dokumentów książęcych w Wielkopolsce do końca XIII w., Lublin 2005. A. Gut rozwinęła swe poglądy na klauzulę pertynencyjną w artykule: Formuła pertynencyjna dokumentów książąt zachodniopomorskich w XII i XIII wieku, [w:] Formuła, archetyp i konwencja w źródle historycznym, red. K. Skupieński, A. Górak, Lublin 2006, s. 83-98, gdzie uznała za wiarygodne najstarsze klauzule pertynencyjne, aż do czasu pojawienia się dokumentu wystawcy, kiedysporządzających akta zaczęły obowiązywać pewne stałe, utarte schematy.

${ }^{15}$ Zob. dla przykładu F. Sikora, Uwagi o dokumentach klasztoru cysterek w Owińskach, „Studia Źródłoznawcze”, t. 9, 1964, s. 65. Natomiast zupełnym zaufaniem darzy klauzulę pertynencyjnq O. Borkowski, Powstanie i rozwój opactwa cysterskiego w Paradyżu Gościkowie w XII-XIV w., „Rocznik Lubuski”, t. 14, 1986, s. 196 i nn., który przyjmuje wszystkie wymienione w klauzuli użytki za rzeczywiście przekazane opactwu. 
Osobiście ${ }^{16}$ za przedmiot klauzuli pertynencyjnej przyjmuję, za R. Hubem oraz S. Russockim ${ }^{17}$, poszczególne przynależności nieruchomości ${ }^{18}$. Klauzula pertynencyjna występowała głównie na tych dokumentach książąt wielkopolskich, które dotyczyły obrotu ziemią, przede wszystkim na nadaniach-darowizny ${ }^{19}$, ale też pojawiała się na dokumentach zamiany ${ }^{20}$, kupna-sprzedaży ${ }^{21}$ czy zastawu $^{22}$.

${ }^{16}$ Rozbioru dyktatu interesujących nas dokumentów na podstawie analizy klasycznych formuł dokonano już w literaturze dla wszystkich wielkopolskich dokumentów książęcych sprzed końca XIII w. Z ważniejszych prac zob.: K. Maleczyński, Studia nad dyplomami i kancelariq Odonica i Laskonogiego 1202-1239, Lwów 1928; Z. Kozłowska-Budkowa, [Rec.] K. Maleczyński, Studia nad dyplomami Odonica i Laskonogiego 1202-1239, Lwów 1928, „Kwartalnik Historyczny”, t. 43, 1929, s. 46-61; S. Kętrzyński, Michat i Konrad, dwaj dyktatorzy kancelarii wielkopolskiej w połowie XIII w., [w:] Księga pamiątkowa ku czci O. Balzera, t. 1, Kraków 1925, s. 21-30; M. Bielińska, Kancelarie i dokumenty wielkopolskie XIII w., Wrocław 1967; F. Sikora, Dokumenty i kancelarie Przemysła I oraz Bolesława Pobożnego 1239-1279 na tle współczesnej dyplomatyki wielkopolskiej, Wrocław 1969; S. Krzyżanowski, Dyplomy i kancelaria Przemysława II. Studium z dziejów dyplomatyki polskiej XIII w., „Pamiętnik Akademii Umiejętności”, Wydział Historyczno-Filozoficzny, t. 8, 1890, s. 122-192 oraz K. Maleczyński, Zarys dyplomatyki polskiej wieków średnich, cz. 1, Wrocław 1951, s. 153-189.

${ }_{17}$ Patrz przypisy nr 9 i 11.

18 W literaturze zachodniej klauzulę pertynencyjną wyróżnia m.in. Vocabulaire, s. 58: La formule de pertinence est celle qui, dans un acte, accompagne le plus souvent toute mention concernant un bien immobilier pour énumérer et préciser l'extension des choses et des droits qui ressortissent à ce bien oraz H. Fichtenau, Forschungen über Urkundenformeln, ein Bericht, „, Mitteilungen des Instituts für österreichischer Geschichtsforschung", t. 94, 1986, s. 318.

19 Kodeks Dyplomatyczny Wielkopolski, t. 1-4, wyd. I. Zakrzewski, Poznań 1877-1881 (dalej: KDW), t. 1, nr 64, 65, 66, 73, 81, 138, 141, 145, 146, 147, 148, 152, 154, 192, 194, 195, 199, 200, 202, $238,249,256,262,264,278,284,288,303,311,351,364,377,379,382,394,393,488,489,493,509$, $518,532,534,536,545,550,559,568,570,576$; t. 2, nr 624, 625, 640, 653, 665, 694, 701, 736, 743 (tu nadanie księcia zostało połączone z nadaniem zwolnień immunitetowych oraz z konfirmacją wcześniejszych nadań), 744; t. 4 (141a); Kodeks Dyplomatyczny Wielkopolski, t. 6, wyd. A. Gąsiorowski, H. Kowalewicz, Warszawa 1982 (dalej: KDW 2), nr 9, 13, 18, 21, 29, 40; M. Bielińska, op. cit., Aneks nr 5; T. Jurek, Dokumenty fundacyjne opactwa w Lqdzie, „Roczniki Historyczne”, t. 66, 2001 - dokumenty darowizny in negotiis prorpiis księcia oraz KDW, t. 1, nr 63, 82, 130, 131, $136,205,245,252,283,285,286,306,313,337,375,376,391,392,404,473,475,484,504,518,539$, 57; KDW 2, nr 38 - dokumenty książęce wystawiane in negotiis alienis; KDW, t. 1, nr 287, 291, 357, 383 - testamenty.

${ }^{20} \mathrm{KDW}$, t. 1, $\mathrm{nr}$ 159, 299, 301, 315, 320; ibidem, t. 2, 689 - dokumenty zamiany in negotiis propriis księcia; ibidem, t. 1, nr 335, 395, 408, 419, 566; ibidem, t. 2, nr 619, 629, 644, 698, 721; Codex diplomaticus nec non epistolaris Silesiae, t. 1, ed. K. Maleczyński, Wrocław 1951 (dalej: KDŚl), t. 1, nr 59 - dokumenty książęce zamiany, wystawiane in negotiis alienis.

${ }^{21} \mathrm{KDW}, \mathrm{t} .1$, nr 494 - dokument kupna-sprzedaży in negotiis propriis księcia; ibidem, t. 1, nr 333, 338, 397, 562; ibidem, t. 2, nr 634.

${ }^{22}$ Ibidem, t. 1, nr 69; ibidem, t. 2, nr 704, 705. 
Występowała ponadto na praktycznie wszystkich formularzach prawnych. Pojawiła się na przywilejach immunitetowych ${ }^{23}$, konfirmacji $^{24}$, transumpcie ${ }^{25}$, restytu$\mathrm{cji}^{26}$, ordynacji-rozporządzeniu ${ }^{27}$, wyroku ${ }^{28}$, na dokumentach lokacyjnych ${ }^{29}$ oraz na dokumentach układu politycznego ${ }^{30}$. Jednakże, co już stwierdzono w literaturze $^{31}$, klauzula pertynencyjna nie stanowiła niezbędnego elementu przy nadaniach nieruchomości. W przebadanym materiale odnajduję wiele dokumentów dotyczących obrotu ziemią, na których klauzula pertynencyjna jest nieobecna ${ }^{32}$.

Klauzula pertynencyjna pojawia się na dokumentach książęcych z terenów średniowiecznej Wielkopolski, jeśli założymy za T. Jurkiem autentyczność oraz antedatowanie dokumentu fundacyjnego klasztoru w Lądzie, w połowie lat 90. XII w. ${ }^{33}$ Jednakże kształt klauzuli, którą posiada dokument fundacyjny opactwa lądzkiego, w podobnej formie zaczyna występować na dokumentach tegoż klasztoru dopiero od lat 50. XIII w. ${ }^{34}$ Następnym dyplomem, zaopatrzonym w klauzulę pertynencyjna, wystawionym przez księcia wielkopolskiego, jest dokument Mieszka III z 26 IV 1177 r. przeznaczony dla cystersów z Lubiąża ${ }^{35}$. Za najwcześniejszy zaś przypadek użycia klauzuli pertynencyjnej na dokumencie książęcym przeznaczonym dla odbiorcy znajdującego się na terenach Wielkopolski uznaję dyplom Władysława Laskonogiego z dnia 16 IV 1208 r., wystawiony dla

\footnotetext{
${ }^{23}$ Ibidem, t. 1, nr 68, 441, 447 (w połączeniu z lokacją).

${ }^{24}$ Ibidem, t. 1, nr 11, 117, 179, 213, 277, 372, 381, 496, 507, 516; ibidem, t. 2, nr 670, 724, 740; KDW 2, $\mathrm{nr} 31$.

${ }^{25}$ Ibidem, t. 1, nr 368; KDW II, 719; ibidem, t. 4, 2058 (739a); KDW 2, 27.

${ }^{26}$ Ibidem, t. 1, nr 540. Zob. też ibidem, t. 1, nr 68, który jest wielkim przywilejem immunitetowym, ale zawiera również restytucję dóbr.

27 Ibidem, t. 1, nr 486.

${ }^{28}$ Ibidem t. 1, nr 373, 378, 387, 415, 420, 553, 561; ibidem, t. 2, nr 737.

${ }^{29}$ Ibidem, t. 1, nr 121, 142, 321, 330, 346, 350, 433, 453, 498, 547, 615 (495a); ibidem, t. 2, nr 641, 642,672 .

${ }^{30}$ Ibidem, t. 1, nr 168, 297.

${ }^{31}$ H. Fichtenau, Forschungen, s. 318, A. Gut, op. cit., s. 160.

${ }^{32}$ Wystarczy porównać listę dokumentów opatrzonych klauzulą pertynencyjną z wykazem dokumentów książąt wielkopolskich, przykładowo darowizny, i to zarówno in negotiis propriis księcia, jak i wystawianych in negotiis alienis, aby przekonać się, iż oba zestawienia nie pokrywają się ze sobą.

${ }^{33}$ T. Jurek, op. cit., nr 2.

${ }^{34}$ Zob. przypis nr 76 .

${ }^{35}$ KDŚl., t. 1, nr 59. Dokument ten posiada 2 klauzule pertynencyjne w brzmieniu: ville Bogunovo et Dobrogoztovo cum circuitionibus suis et omnibus attinentiis oraz locus, qui vocatur Zlup cum circuitione sua et omnibus attinentiis.
} 
cystersów w Łeknie ${ }^{36}$. Klauzula pertynencyjna pojawia się na dyplomach redakcji mnichów łekneńskich jeszcze dwukrotnie w drugim dziesięcioleciu XIII w., kolejno w latach 1211 oraz 1214, od razu w dość rozbudowanym kształcie ${ }^{37}$. Klauzula pertynencyjna na dokumentach książąt wielkopolskich dla odbiorców spoza terenów Wielkopolski jest również obecna na 2 dyplomach Władysława Odonica dla klasztorów w Lubiążu ${ }^{38}$ i Trzebnicy ${ }^{39}$, datowanych na 1209 r. oraz precyzyjniej na 25 III 1209 r. Kolejnym chronologicznie dokumentem książęcym, posiadającym w swym formularzu dwie klauzule pertynencyjne, przy czym jedną z nich, również w już rozbudowanym kształcie, jest dokument fundacyjny klasztoru w Przemęcie, wystawiony 29 VI 1210 r. $^{40}$ Następnie klauzula pertynencyjna występuje na dokumencie Władysława Odonica, Leszka Białego, Konrada Mazowieckiego oraz Kazimierza Opolskiego, wystawionym dla arcybiskupstwa gnieźnieńskiego i datowanym na 4 IX 1210 r.-16 V $1211 \mathrm{r}^{41}$ Ostatnie przykłady wystąpienia klauzuli pertynencyjnej z najwcześniejszego okresu jej używania w średniowiecznej Wielkopolsce stanowią dyplomy: Władysława Odonica z 28 VI 1211 r. - przeznaczony dla kościoła NMP we Wrocławiu ${ }^{42}$, oraz z 20 X 1213 r. wystawiony dla klasztoru cysterek w Ołoboku ${ }^{43}$. Spośród odbiorców dokumentów książąt wielkopolskich, ale spoza terenów Wielkopolski, w drugim dziesięcioleciu XIII w., to jedynie kościół NMP we Wrocławiu otrzymał dokument zaopatrzony w klauzulę pertynencyjną ${ }^{44}$. Następnie, poza przypadkiem użycia klauzuli pertynencyjnej na 2 dyplomach Władysława Odonica z 2 X 1225 r. i 25 IV 1228 r.,

36 KDW, t. 1, nr 63.

37 KDW, t. 1, nr 63: hereditatem...cum silvis, aquis, pratis vel agris; ibidem, t. 1, nr 69: predium... cum duobus lacubus adiacentibus, scilicet Belsko et Scekolin, cum omnibus attinenciis, pratis et nemoribus, quorum hec sunt vocabula: Carciles, Cronekir et Swiniblota, cum agris et aquis; ibidem, t. 1, nr 82: hereditates, videlicet Raccove et Gromadno..., cum omnibus utilitatibus que nunc in eis sunt vel in posterum esse possunt, videlicet cum silvis, aquis, pratis, campis vel agris.

${ }^{38}$ Ibidem, t. 1, nr 65: villam...cum mellificis et lacu nomine Tuchno, et laci alterius medietate eidem ville pertinente cuius laci vocabulum est Radechovo, et cum universis memorate hereditatis appendiciis.

39 Ibidem, t. 1, nr 64: aquam cum castoribus.

40 Ibidem, t. 1, nr 66: 1. locum qui Polonica lingua Virchuie dicitur cum circumiacentibus lacubus et nemoribus oraz 2. possessions...cum attinentiis suis cultis et incultis, viis et inviis, agris, aquis et silvis, pratis et paschuis, nemoribus et venationibus, lacubus et piscationibus, aucupiis et navigiis, cum omni libertate et utilitate que in presntiarum inest vel inesse poterit in futurum.

41 Ibidem, t. 1, nr 68: villas...et silvas cum suis utilitatibus.

42 Ibidem, t. 1, nr 73: villam cum lacu iuxta Szrem, nomine Muchino.

43 Ibidem, t. 1, nr 81: partem aque que Prosna vocatur cum castoribus.

44 Ibidem, t. 1, nr 64: villam cum lacu iuxta Szrem, nomine Muchino. 
dla cystersów w Lubiążu ${ }^{45}$, oraz na dokumencie tegoż władcy wystawionym dla templariuszy z $1225 \mathrm{r}^{46}$, omawiana klauzula zaczyna pojawiać się na dokumentach książęcych od początku lat 30. XIII w. ${ }^{47}$ Dopiero od tego momentu klauzula owa staje się jednym z najczęściej stosowanych elementów formularza dyspozycji dokumentów książęcych w Wielkopolsce ${ }^{48}$.

Klauzula pertynencyjna pojawiła się jednak wcześniej na innych dokumentach niż książęce ${ }^{49}$. Już na dokumencie Zbyluta odnotowano, iż klasztor w Łeknie otrzymał m.in. Ergelzko cum lacu integro ${ }^{50}$. Jednakże przed początkiem czwartego dziesięciolecia XIII w. pojawia się na takich dokumentach jeszcze tylko raz - w 1215 r. na dokumencie wystawionym przez Mengoza, prepozyta trzemeszeńskiego, oraz Guntera, dziekana płockiego, dla norbertanek w Strzelnie ${ }^{51}$. Klauzula pertynencyjna, z wyodrębnionego właśnie najwcześniejszego okresu, w obu przypadkach jej użycia na innych dokumentach niż książęce, posiada zawsze bardzo skromny kształt ${ }^{52}$.

Przejdę teraz do przeglądu form redakcyjnych klauzuli pertynencyjnej. W wypadku dokumentów arcybiskupstwa gnieźnieńskiego oraz biskupstwa poznańskiego nie wykluczam możliwości stosowania przez pisarzy pewnych schematów redakcyjnych klauzuli pertynencyjnej, które nie znalazły zastosowania na

${ }^{45}$ Ibidem, t. 1, nr 116: Territorium...cum omni iure habeat sicut domus Lubensis suum, cum lacubus qui in ipso continetur, id est tria Sicove, cum terris et pratis et aliis utilitatibus oraz ibidem, t. 1, nr 121: tria milia mansorum...cum omni utilitate, videlicet agris, pratis, pascuis, aquis, lacubus, castoribus, piscationibus, venationibus et omnibus aliis proventibus qui nobis et nostris successoribus deberent provenire, dokument posiada również drugą klauzulę pertynencyjnq w kształcie: tres... forenses civitates, cum moneta speciali.

${ }^{46}$ Ibidem, t. 1, nr 117: Drosin cum foro et thaberna.

47 Ibidem, t. 1, nr 130, 131, 136, 138, 141, 142, 145, 146, 147, 148, 152, 154, 159, 168, 179, 192, 194, 195, 199, 200, 202, 205, 213; ibidem, t. 4, nr 2054 (141a).

${ }^{48}$ Por. odnalezione przez nas przykłady klauzuli pertynencyjnej na dokumentach książęcych: ibidem, t. 1, nr 235, 238, 245, 249, 252, 256, 262, 264, 277, 278, 283, 284, 285, 286, 287, 288, 291, 297, 299, 301, 303, 306, 311, 313, 315, 320, 321, 330, 333, 335, 337, 338, 344, 346, 350, 351, 357, 364, 368, $372,373,375,376,377,378,379,381,382,383,384,387,391,392,393,395,397,404,408,415,419$, 420, 433, 441, 447, 453, 473, 475, 478, 484, 486, 488, 489, 493, 494, 496, 498, 504, 507, 509, 516, 518, $532,534,536,539,540,545,547,550,553,559,561,562,566,568,570,573,576,615$ (495a); KDW t. II, nr 618, 619, 624, 625, 629, 634, 640, 641, 642, 644, 653, 665, 670, 672, 689, 693, 694, 698, 701, 704, 705, 719, 721, 724, 725, 736, 737, 740, 743, 744; KDW, t. 4, nr 2058 (739a); KDW 2, nr 9, 13, 18, 21, 27, 29, 31, 38, 40; M. Bielińska, op. cit., Aneks nr 5.

${ }^{49}$ Naturalnie odrzucając wszystkie falsyfikaty datowane na XII w.

${ }^{50} \mathrm{KDW}$, t. 1, nr 18.

${ }^{51}$ Ibidem, t. 1, nr 84: villam Oflucin cum suis apendiciis.

${ }^{52}$ Por. poprzedni przypis oraz zacy towaną powyżej w tekście klauzulę z dokumentu Zbyluta. 
dokumentach wystawianych przez książąt wielkopolskich. Mogły one oczywiście znaleźć swe odbicie na dokumentach wystawianych bądź już przez samych arcybiskupów gnieźnieńskich, bądź przez biskupów poznańskich. Rozbiór wszystkich dokumentów, poza książęcymi, z terenów XIII-wiecznej Wielkopolski nie mieści się jednak w ramach niniejszego tekstu.

Rozpatrując charakterystyczne cechy klauzuli pertynencyjnej redagowanej kolejno przez pisarzy kancelarii książęcej, i to zarówno Przemysła I, Bolesława Pobożnego, jak i Przemysła II, należy podkreślić, że to Michał na 4 dokumenty posiadające klauzulę pertynencyjną ${ }^{53} \mathrm{w} 3 \mathrm{z}$ nich, przeznaczonych dla templariuszy oraz dla cystersów w Łeknie i Paradyżu, z okresu 20 V 1253-18 III 1256 r., użył formy: cum omnibus attinentiis et hutilitatibus suis ${ }^{54}$. Spośród dokumentów przypisywanych dyktatowi Konrada dwukrotnie zastosował on, w ciągu roku 1252, na 2 dokumentach, sporządzonych dla klasztoru w Łeknie oraz dla cystersów w Paradyżu, tej samej redakcji klauzuli pertynencyjnej: cum omnibus que in ea nunc sunt vel in posterum evenire poterunt ${ }^{55}$. Tilo używał najchętniej klauzuli pertynencyjnej w kształcie: cum omnibus utilitatibus et pertinenciis, que nunc ibi sunt et exoriri poterunt in futurum ${ }^{56}$, która z różnymi, drobnymi odmianami pojawiała się na dokumentach jego redakcji, przeznaczonych dla Żegoty, palatyna krakowskiego, Bogusława, kasztelana ujskiego i podkomorzego poznańskiego, oraz dla arcybiskupów gnieźnieńskich ${ }^{57}, 4$ razy w ciągu roku 1284, tj. od 8 I do $6 \mathrm{X}^{58}$. Natomiast na dwóch pozostałych dokumentach swojej redakcji, z 5 XI $1282 \mathrm{r}^{59}$ oraz 17 II 1284 r. $^{60}$, przeznaczonych dla templariuszy oraz Gosława, dziekana arcybiskupstwa gnieźnieńskiego, i posiadających klauzulę pertynencyjną, posłużył

53 Ibidem, t. 1, nr 315, 330, 333, 335.

54 Ibidem, t. 1, nr 333; 335 oraz ibidem, t. 1, nr 315, która na ostatnim z wymienionych dokumentów została jednakże rozszerzona: cum omnibus attinenciis et utilitatibus earum que nunc in eis sunt vel in posterum poterunt provenire. Dwa dokumenty z zacytowanych przed chwilą (najwcześniejszy i najstarszy) są zaopatrzone w dodatkowe klauzule pertynencyjne.

55 Tak ibidem, t. 1, nr 301. Por. Ibidem, t. 1, nr 306, tu w trochę innym wariancie: cum omnibus utilitatibus que in ea sunt vel in posterum devenire poterint.

56 Ibidem, t. 1, nr 536.

57 To właśnie arcybiskupi gnieźnieńscy wśród dokumentów analizowanej grupy otrzymali 2 dyplomy.

${ }_{58} \mathrm{KDW}, \mathrm{t} .1$, nr 539: cum omnibus utilitatibus et pertinenciis nunc ibi existentibus et provenientibus in futurum; ibidem, t. 1, nr 545: cum omnibus utilitatibus et proventibus que ibi sunt et processu temporis poterunt exoriri; oraz w nieco rozszerzonej formie ibidem, t. 1, nr 532: cum omnibus iuribus, utilitatibus et pertinentiis ipsius, existentibus et futuris, in terra et aqua.

59 Ibidem, t. 1 , nr 516.

60 Ibidem, t. 1, nr 534 . 
się już skromniejszą formą: cum omnibus suis utilitatibus et pertinentiis ${ }^{61}$. Jasiek opatrywał redagowane przez siebie dyplomy najczęściej klauzulą pertynencyjna, która w najogólniejszej swej redakcji oparta była na zwrocie wymieniającym zawsze prawa i przynależności, jakie w owym czasie i w przyszłości posiadała oraz miała posiadać dana darowizna, i która brzmi: cum omni iure et utilitate, que inibi sunt in presenti et haberi in futurum ${ }^{62}$, a która z różnymi, niewielkimi odmianami wystąpiła na $6 \mathrm{z} 10$ zredagowanych przezeń dokumentó ${ }^{63} \mathrm{w}$ okresie od 9 IX 1286 r. do 30 IV 1293 r., wystawionych dla 3 różnych odbiorców, tj. protonotariusza książęcego Tilona, cystersów w Obrze oraz biskupstwa poznańskiego ${ }^{64}$. Trzy pozostałe dokumenty, których redakcję przypisuje się Jaśkowi, posiadają już odmienną, skromniejszą formę i przeznaczone zostały dla 3 różnych odbiorców: dla biskupstwa poznańskiego, Zdzisława i komesa Tarswina ${ }^{65}$. Na pozostałych dyplomach zredagowanych przez pisarzy wielkopolskiej kancelarii książęcej nie dostrzegam już jakichś typowych, powtarzających się kształtów klauzuli pertynencyjnej.

Na nielicznych dokumentach książęcych wystawionych na rzecz arcybiskupstwa gnieźnieńskiego można wskazać na pewien charakterystyczny kształt klauzuli pertynencyjnej. Na 4 bowiem dokumentach z okresu 1236 r.-26 IV 1286 r. $^{66}$ zredagowano klauzulę pertynencyjna, opierając jej kształt na zwrocie: cum omnibus utilitatibus que in eis sunt vel haberi possunt, który samodzielnie posłużył za

${ }^{61}$ Tak na dokumencie wymienionym w poprzednim przypisie. Dyplom wcześniejszy posiada nieznacznie zmienioną wersję tej samej formy omawianej klauzuli: cum eorum omnibus attinenciis et proventibus.

${ }^{62} \mathrm{KDW}, \mathrm{t} .2, \mathrm{nr} 693$.

${ }^{63}$ Ibidem, t. 1, nr 568, 573; ibidem, t. 2, nr 619, 625, 642, 689, 693, 694, 701.

${ }^{64}$ Ibidem, t. 1, nr 568: cum omni iure et dominio que ipsam possedimus, et lacu ibidem integraliter existente; ibidem, t. 1, $\mathrm{nr}$ 573: cum omni iure quo dictam hereditatem possidebant et omnibus fructibus et utilitatibus; ibidem, t. 2, nr 625: cum omni iure quo ipsam possedimus et tenuimus; ibidem, t. 1, nr 689: cum omni iure et utilitate, lacubus et libertate quam omnes ville Poznaniensis ecclesie antiqutus possesse habuerunt et habent; ibidem, t. 2, $\mathrm{nr}$ 694: cum omni iure, utilitate ac libertate ea, quam omnes ville antique ecclesie predicte habent et a nostris parentibus habueunt. Odbiorcą zarówno 3 ostatnich wymienionych tu dokumentów, jak i dyplomu zacytowanego w poprzednim przypisie było. biskupstwo poznańskie.

${ }^{65}$ Ibidem, t. 2, $\mathrm{nr} 619$ posiada dwie klauzule pertynencyjne: cum omnibus iuribus, pertinenciis et libertatibus oraz cum omnibus villis et pertinenciis eiusdem, ibidem, t. 2, $\mathrm{nr}$ 642: cum omnibus utilitatibus, ibidem, t. 2, nr 701: cum omnibus utilitatibus secundum quod nos habuimus libere.

${ }^{66}$ Chodzi tu o dokumenty KDW, ibidem, t. 1, nr 199, 288, 299 oraz 562. 
redakcję całej klauzuli na dokumencie wystawionym 20 I $1252 \mathrm{r}^{67} \mathrm{~W}$ rozbudowanym już nieco kształcie powyższa redakcja pojawia się jeszcze trzykrotnie ${ }^{68}$.

Pomimo że nie jest możliwe wskazanie na identyczne kształty klauzuli pertynencyjnej, w którą mnisi łekneńscy zaopatrywali redagowane przez siebie dokumenty, to można, jak się wydaje, wykazać charakterystyczną cechę omawianej klauzuli. Na 7 dokumentów książęcych zredagowanych w klasztorze, posiadających klauzulę pertynencyjna, aż $5 \mathrm{z}$ nich z okresu 16 IV 1208 r.-16 IV 1259 r. wymienia praktycznie zawsze te same przynależności: lasy, wody, łąki oraz pola ${ }^{69}$, przy czym dwukrotnie przynależności zostają rozszerzone: za pierwszym razem dodatkowo o pola ${ }^{70}$, za drugim razem - o gaje ${ }^{71}$. Ten sam podstawowy zestaw przynależności zawiera również dokument wystawiony przez Zbyluta, kasztelana nakielskiego, 25 VII 1286 r. dla opactwa łekneńskiego ${ }^{72}$.

W przypadku klauzuli pertynencyjnej redagowanej przez cystersów lędzkich można z łatwością wskazać jej charakterystyczne formy. W najogólniejszym swym kształcie brzmi ona następująco: cum hominibus et cum omnibus utilitatibus que in eis sunt ac in posterum provenire poterunt ${ }^{73}$. W takiej redakcji omawiana klauzula występuje na dokumencie fundacyjnym opactwa, datowanym na 23 IV $1145 \mathrm{r}^{74}$ Następnie, w prawie niezmienionym kształcie, będąc tylko czasami rozszerzaną

${ }^{67}$ Ibidem, t. 1, nr 199.

${ }^{68}$ Ibidem, t. 1, $\mathrm{nr}$ 199: cum omni suo iure ac districtu, cum castoribus et venationibus et omnibus aliis utilitatibus que in ea sunt vel haberi possunt; ibidem, t. 1, $\mathrm{nr}$ 288: cum lacu et omnibus eius pertinenciis ac omnibus aliis utilitatibus que in eadem villa sunt vel haberi possunt; ibidem, t. 1, nr 562; cum omni iure, pleno dominio et utilitatibus quibuslibet, que ibi habentur vel haberi poterunt in futuro.

${ }^{69}$ Ibidem, t. 1, nr 63, 69, 79 oraz ibidem, t. 1, nr 373: sortium adiacentium, videlicet Slosin, Dvorove, Croverkir, Sviniblota et Cycino cum nemoribus et silvis, agris, pratis et aquis iam dudum vertebatur.

${ }^{70}$ Ibidem, t. 1, nr 82. Tu oddane za pomocą rzeczownika campus.

${ }^{71}$ Ibidem, t. 1, nr 373 .

${ }^{72}$ Ibidem, t. 1, nr 567: cum silvis, agris, pratis, videlicet aquis, cum omnibus suis pertinentiis.

${ }^{73}$ Ibidem, t. 1, nr 10; T. Jurek, op. cit., nr 2.

${ }^{74}$ Dokument ten posiada $2 \mathrm{w}$ zasadzie identycznie zredagowane formuły pertynencyjne, druga brzmi następująco: cum hominibus et omnibus utilitatibus que in eis sunt et post successive esse poterunt. 
bądź zawężaną, klauzula ta trafiła na 5 dokumentów klasztornych z okresu $15 \mathrm{~V} 1253 \mathrm{r}$. -15 VIII $1288 \mathrm{r}^{75}$ oraz na 2 transumpty dokumentu fundacyjnego ${ }^{76}$. Za najbardziej charakterystyczny kształt klauzuli pertynencyjnej dokumentów paradyskich i oberskich ${ }^{77}$ uznaję: cum omnibus attinenciis suis, który z niewielkimi odmianami ${ }^{78}$ wystąpił 14 razy $^{79}$. Pierwszy raz klauzula pertynencyjna, we wskazanej powyżej redakcji, pojawiła się na dokumencie Przemysła I z 14 VI 1245 r., wystawionym dla klasztoru cystersów w Obrze ${ }^{80}$. Natomiast po raz ostatni wystąpiła w XIII stuleciu na dokumentach zredagowanych w Obrze i Paradyżu oraz na dyplomie Bolesława Pobożnego z 2 VII 1263 r., wystawionym dla opactwa paradyskiego ${ }^{81}$.

Wydaje się, iż nawet przy pewnym zróżnicowaniu poszczególnych redakcji klauzuli pertynencyjnej, występującej na dokumentach cysterek z Owińsk i Ołoboku $^{82}$, można wskazać kilka charakterystycznych jej cech. Przede wszystkim na

${ }^{75} \mathrm{KDW}, \mathrm{t} .1$, nr 313: cum omnibus sortibus attinentibus prout in presenciarum possidet; ibidem, t. 1, nr 385: cum omnibus attinentiis suis; ibidem, t. 1, $\mathrm{nr}$ 488: cum omnibus lacubus et utilitatibus que nunc in eis sunt vel fieri poterunt (dyktat dokumentu jest wprawdzie przypisywany kancelarii książęcej, patrz przypis nr 17); ibidem, t. 2, nr 629: cum omnibus utilitatibus que nunc in ea sunt ac in posterum poterunt exoriri; KDW, t. 2, $\mathrm{nr}$ 13: cum omnibus utilitatibus prefate ville spectantibus eis. Również falsyfikat dokumentu Władysława Odonica z 21 X 1233 r. posiada niezwykle skróconą klauzulę, pozbawioną wzmianki o przyszłych przynależnościach, którą można by ewentualnie wyprowadzać ze schematu lędzkiej klauzuli pertynencyjnej, ukazanej powyżej: cum omnibus utilitatibus suis. Omawiany dokument posiada aż 3 klauzule pertynencyjne.

${ }^{76}$ Ibidem, t. 1, nr 393: cum hominibus simul et cum omnibus utilitatibus tam presentibus quam futuris; KDW, t. 2, nr 27: cum hominibus et omnibus utilitatibus, que in eis sunt ac in posterum provenire poterunt.

77 W klasztorze w Paradyżu redagowano też dokumenty oberskie, stąd analizuję je razem, patrz przypis $\mathrm{nr} 17$.

${ }^{78}$ Ibidem, t. 1, nr 245 nie posiada określenia suis, ibidem, t. 1, nr 252 posiada z kolei uzupełnienie poprzez dodanie et terminis, a KDW, ibidem, t. 1, nr 335 hutilitatibus, ibidem, t. 1, nr 397 w miejsce suis posiada earum, podobnie ibidem, t. 1, nr 408, precyzując dwukrotnie: ipsarum.

79 Ibidem, t. 1, nr 245, 252, 278, 283, 285, 286, 335 (redakcja dokumentu jest przypisywana pisarzowi kancelarii książęcej Michałowi, patrz przypis nr 18), 337, 338, 383 (przy czym dokument ten posiada dwie różne klauzule pertynencyjne), 392, 397, 408 (dokument ten posiada dwie klauzule pertynencyjne, obie w identycznym kształcie).

${ }^{80}$ Ibidem, t. 1, nr 245.

${ }^{81}$ Ibidem, t. 1, nr 408.

${ }^{82}$ W Owińskach redagowano też dokumenty klasztoru w Ołoboku, zob. przypis nr 17, dlatego rozpatruję je razem. Patrz dokumenty cysterek w Owińskach i Ołoboku zaopatrzone w klauzulę pertynencyjną: ibidem, t. 1, nr 81, 277 (dyktat tego dokumentu przypisuje się kancelarii książęcej, patrz przypis nr 18), 284, 303, 311, 496, 518. 
2 dokumentach, Przemysła I z 26 IV 1252 r. $^{83}$ oraz Przemysła II z 3 VII 1280 r. $^{84}$, klauzula pertynencyjna przyjmuje praktycznie ten sam kształt: et universis utilitatibus, videlicet silvis, pratis, pascuis, agris, aquis, molendinis, piscibus, castoribus, venacionibus ${ }^{85}$. Kolejną cechą typową dla analizowanej klauzuli dokumentów cysterek z Owińsk i Ołoboku jest okoliczność wymieniania bobrów w 6 na 8 dyplomów ${ }^{86}$. Ostatnim elementem godnym tutaj odnotowania są rozmiary klauzuli pertynencyjnej redagowanej w tychże klasztorach, występującej na 2 dokumentach, których autentyczności jeszcze nikt do tej pory nie podważył ${ }^{87}$.

Pięć dokumentów, w tym cztery książęce, opactwa w Dobrymługu, z przedziału czasowego 1259 r.-1 VII 1260 r., charakteryzuje praktycznie zawsze jednakowa klauzula pertynencyjna, występująca $\mathrm{w}$ dwóch wariantach: omnibus utilitatibus, videlicet lacubus, silvis, pratis, et si que alie utilitates sint vel erunt, libere perfruantur $^{88}$ oraz: cum omni utilitate, scilicet agris, pratis, silvis et aquis et pleno iure tam proprietatis quam possessionis ${ }^{89}$. Klauzula pertynencyjna na dokumentach

83 Ibidem, t. 1, nr 303.

84 Ibidem, t. 1, nr 496. Obie przytoczone powyżej klauzule stanowią, wyróżnioną przeze mnie, klauzulę korzystania $z$ użytków, która poprzez swą formę redakcyjną przybiera nieraz kształt charakterystyczny dla klauzuli pertynencyjnej. Zob. jak w przypisie nr 15.

85 Tak na starszym dokumencie, na młodszym omawiana klauzula została tylko nieznacznie rozszerzona: cum universis utilitatibus, videlicet silvis, pratis, pascuis, agris, aquis, molendidnis, piscibus, castoribus, venacionibus cum aliis utilitatibus.

86 KDW, t. 1, nr 81, 277, 284, 303, 496.

87 Ibidem, t. 1, nr 284: cum omnibus que in prefate circuitu et ambitu sunt vel esse possunt in futurum, videlicet silvis, nemoribus, rubetis, agris, pratis, pascuis, paludibus, lacubus, aquis, aquarum decursibus, molendinis molendinorumque locis, piscaturis, castoribus, venacionibus, mellificis, ac aliis omnibus dominiis et utilitatibus prout ad nos a progenitoribus nostris pertinebant oraz ibidem, t. 1, nr 518: cum omni iure et utilitate, videlicet silvis, nemoribus, pratis, pascuis, agris cultis et incultis, stagnis, piscaturis, aquarum decursibus, molendinis, et aliis omnibus usibus qui nunc sunt in eis vel in posterum possint provenire.

88 Ibidem, t. 1, nr 375. Dokument posiada również drugą klauzulę pertynencyjną: cum omnibus terminis suis, stanowiącą jedyny wypadek użycia na dokumentach książęcych tego opactwa innej formy tejże klauzuli. Identycznie zredagowaną klauzulę pertynencyjną ma KDW, t. 1, nr 376, który stanowi drugi, identyczny egzemplarz poprzedniego dokumentu, przy czym zacytowane powyżej w tekście klauzule stanowią, ściśle rzecz ujmując, klauzulę korzystania z użytków, kształtem redakcyjnym jednakże nieodbiegającą często od klauzuli pertynencyjnej, o czym zob. powyżej, jak w przypisie nr 85. Na KDW, t. 1, nr 387, zredagowano identycznie jak wskazaną przeze mnie niejako podstawową klauzulę, zmieniono jedynie przynależności, jakie ma posiadać nadanie bądź darowizna: omnibus utilitatibus, videlicet aquis, silvis, agris, pratis, pascuis, piscationibus, mellificis et si que alie utilitates sint vel erunt, libere perfruantur.

${ }^{89}$ Ibidem, t. 1, nr 381 - dyktat dokumentu przypisuje się wprawdzie w literaturze pisarzowi kancelarii książęcej Piotrowi, patrz przypis nr 17 - oraz na dokumencie komesa Eustachego z 1 VII 
cystersów z Dobregoługu występuje jedynie w tym okresie, i to na dokumentach zarówno książęcych, jak i prywatnych ${ }^{90}$.

Wśród dokumentów templariuszy wielkopolskich mogę wskazać na 2 typy klauzuli pertynencyjnej. Pierwszym typem omawianej klauzuli jest: cum omni utilitate, que in presenti eis et in futuro suppetere poterunt - znany z dokumentu Władysława Odonica z $1232 \mathrm{r}^{91}$, nieznacznie rozszerzony pojawił się na dokumencie tego władcy jeszcze raz tego samego roku ${ }^{92}$. Kolejna redakcja klauzuli pertynencyjnej dyktatu templariuszy występuje wprawdzie dwukrotnie, ale za każdym razem na tym samym dokumencie. $\mathrm{Z}$ tego typu przypadkiem mamy do czynienia na wspomnianym przed chwilą dokumencie Władysława Odonica $\mathrm{z} 1232 \mathrm{r}^{93}$, na którym klauzula pertynencyjna wystąpiła czterokrotnie, w tym dwa razy w skromnym kształcie: cum omnibus suis attinentiis.

Spośród 4 dokumentów książęcych, jakie otrzymał klasztor dominikanów poznańskich w XIII w., pomimo zróżnicowania większości form klauzuli pertynencyjnej ${ }^{94}$, odnotuję jednakże 2 wypadki zastosowania takiej samej redakcji: cum lacubus et omnibus aliis utilitatibus que in eisdem hereditatibus nunc sunt et in posterum poterunt reperiri ${ }^{95}$.

Na 2 dokumentach z lat 1284 i 1295, jakie otrzymały klaryski gnieźnieńskie od Przemysła II, klauzula pertynencyjna wystąpiła aż trzykrotnie, ale w dwóch wypadkach oparto ją na jednym i tym samym schemacie: cum omnibus utilitatibus seu proventibus qui nunc ibidem sunt vel in posterum fieri poterunt ${ }^{96}$.

$1260 \mathrm{r}$., ibidem, t. 1, $\mathrm{nr} 385$, choć tu w nieco rozszerzonej postaci: cum omni utilitate in agris, pratis, silvis, aquis, piscationibus, mellificis, et cum omni libertate et pleno iure tam proprietatis quam possessionis.

${ }^{90}$ Natomiast ani dokument Przemysła II (ibidem, t. 1, nr 576), ani biskupa poznańskiego Andrzeja (ibidem, t. 1, nr 439), z dokumentów z XIII w. wystawionych dla klasztoru w Dobrymługu nie posiadają w ogóle klauzuli pertynencyjnej.

${ }^{91}$ Ibidem, t. 1, $\mathrm{nr} 142$.

92 Ibidem, t. 1, nr 141, brzmi ona następująco: cum omni libertate et utilitate, que eis in presenti suppetere poterunt et in futuro.

${ }_{93}$ Ibidem, t. 1, nr 141.

${ }_{94}$ Por. ibidem, t. 1, nr 484; 489; 504 oraz KDW, t. 2, nr 29.

${ }_{95}$ Ibidem, t. 1, nr 504, natomiast na KDW, t. 2, nr 29, ta sama klauzula brzmi: cum omnibus utilitatibus et proventibus, quae in eisdem nunc et in perpetuum poterunt inveniri. Oba rozpatrywane dokumenty posiadają również drugą klauzulę pertynencyjną, choć na obu już całkowicie różną.

${ }^{96}$ Dokładnie taki kształt redakcyjny posiada KDW, t. 1 , $\mathrm{nr} 550$, natomiast na ibidem, t. 2 , $\mathrm{nr} 736$, ten sam schemat posłużył redaktorowi dokumentu do wplecenia weń niejako kolejnych przynależności: cum hominibus ministerialibus ibidem existentibus et omnibus utlitatibus seu 
Spośród kilku dyplomów wystawionych przez książąt wielkopolskich dla cystersów w Lubiążu rysuje się dość jasny, jeśli nie cały schemat klauzuli pertynencyjnej, jest to z pewnością katalog wymienianych w niej użytków. Na 6 albowiem dokumentach z okresu 25 IV 1228 r.-21 VIII 1233 r. powtarzają się: łąki, pola, pastwiska, jeziora oraz bobry, a dodatkowo występują: wody, łowy i rybołówstwo ${ }^{97}$.

W przypadku klauzuli pertynencyjnej używanej przez dyktatorów dokumentów w klasztorze w Kołbaczu, nawet pomimo znikomej liczby 5 dokumentów, jakimi rozporządzamy, wydaje się, iż można wydzielić aż 2 typy omawianej klauzuli: węższy i bardziej rozbudowany. Typ węższy, obecny na 3 dokumentach z 1236 r. oraz $1258 \mathrm{r}^{98}$, brzmi praktycznie niezmiennie: cum omnibus attinentiis suis, agris, pratis, aquis, silvis ${ }^{99}$. Szerszy zaś typ obecny jest na 2 dyplomach z 1233 r. oraz 29 VI 1259 r. i przybiera dwukrotnie również ten sam kształt: cum omnibus terminis et attinenciis suis, agris, pratis, pascuis, silvis, cultis et incultis, aquis, stagnis, rivis, piscacionibus, in semitis, viis, et omni utilitate que est in futurum haberi potest ${ }^{100}$.

Dysponując tylko 2 dokumentami wystawionymi przez książąt wielkopolskich dla 2 placówek bożogrobców w Polsce, w Gnieźnie oraz w Miechowie, odnotuję

proventibus qui nunc ibidem sunt vel in posterum fieri poterunt, et cum area ubi idem monasterium est fundatum.

97 Por. ibidem t. 1, nr 152: desertum...cum omni iure et omnibus utilitatibus, videlicet pratis, agris, pascuis, lacubus, castoribus z klauzulą, ibidem, t. 1, nr 121, zacytowaną w przypisie $\mathrm{nr} 314$ oraz ibidem, t. 1, nr 147: tria milia mansorum...cum lacubus, aquis, pascuis que predictis tribus milibus mansis non debent annumerari sed pleni per se; cum omni iure et libertate in castoribus, piscariis, moneta, iudiciis et aliis libertatibus quas contuli cum prima donatione, ibidem, t. 1, nr 218, rozszerzone tu również o ogólnie sformułowane prawa: cum omni iure et omnibus utilitatibus, videlicet pratis, agris, pascuis, venationibus, lacubus, castoribus, piscationibus, ibidem 1, 219: cum omni utilitate, videlicet agris, pratis, pascuis, aquis, lacubus, castoribus, piscationibus, venationibus, et omnibus aliis proventibus qui nobis et nostris successoribus deberent provenire. W tym kontekście por. również klauzulę pertynencyjna dokumentu z $1261 \mathrm{r}$., ibidem, t. 1, nr 390: lacus nostros Dominicz et Luchowo vulgariter nuncupatas...cum omnibus pertinenciis suis videlicet silvis, agris, pratis, pascuis, paludibus et rubetis prout ad dictos lacus antiquitus pertinebant.

${ }_{98}$ Dokument KDW, t. 1, $\mathrm{nr} 154$ jest niedatowany.

99 Ibidem, t. 1, nr 195 oraz w zmienionej kolejności ibidem t. 1, nr 154. Dyplom KDW, t. 1, nr 371, pomija jedynie pola.

${ }^{100}$ Ibidem, t. 1, nr 377, którego dyktat przypisuje się jednak w literaturze pisarzowi kancelarii książęcej Piotrowi, patrz przypis nr 17. Ibidem, t. 1, nr 145, omawiana klauzula jest jedynie poprzedzona nadaniem 2 wsi wraz ze stawem oraz posiada drobne odmiany stylistyczne: Trebenem et Doberpol, cum stagno Zorina et cum omnibus terminis et attinentiis suis, agris, pratis, pascuis, silvis, cultis et incultis, aquis, stagnis, rivis, piscationibus, in semitis et in viis, et omni utilitate que est vel in futuro haberi poterit. 
tutaj, iż na obu dyplomach z 1259 r. oraz z 6 IX 1290 r. klauzula pertynencyjna przybrała dokładnie ten sam kształt: cum omnibus utilitatibus ${ }^{101}$.

Przyglądając się klauzuli pertynencyjnej dokumentów redagowanych przez pisarzy ośrodków, które odznaczały się dużym doświadczeniem kancelaryjnym,można stwierdzić, że nie wymieniano w niej żadnych konkretnych użytków, a ograniczano się jedynie do ogólnych sformułowań, jak: cum omnibus attinenciis suis, np. w Paradyżu ${ }^{102}$. Ten typ klauzuli pertynencyjnej występował w ogromnej większości przypadków na dokumentach redagowanych w kancelarii książęcej, w kancelariach arcybiskupów gnieźnieńskich, biskupów poznańskich, klasztorze lędzkim oraz $\mathrm{u}$ templariuszy wielkopolskich ${ }^{103}$. Natomiast klauzulę pertynencyjnq w mniej kompetentnych kancelaryjnie ośrodkach zdaje się charakteryzować szczegółowy katalog wymienianych użytków, np. na dyplomach cystersów w Łeknie, Dobrymługu czy cysterek w Owińskach i Ołoboku ${ }^{104}$. Wprawdzie jeśli włączyć również odbiorców dokumentów książąt wielkopolskich spoza samej Wielkopolski, to okaże się, że cystersi z Lubiąża oraz z Kołbacza, znani ze swej troski o pisemne zabezpieczenie swego majątku, również redagowali klauzulę pertynencyjna, wymieniając w niej kolejne użytki. Ta okoliczność jednakże nie musi wcale osłabiać mojego przypuszczenia, ponieważ klasztory w Lubiążu oraz w Kołbaczu przynależały do innych linii filiacyjnych niż klasztory wielkopolskie ${ }^{105}$.

\section{Summary}

\section{The Proprietary Clause in the Ducal Documents in Greater Poland till 1296}

The studies on the form and contents of the documents have so far focused on the formulas of the protocol and eschatocol of documents. This article attempts to go beyond these patterns and, by using the example of the analysis of the proprietary clause, show that also the formulas of the context of the document were

\footnotetext{
${ }^{101}$ Ibidem, t. 1, nr 382; ibidem, t. 2, nr 648.

102 Obecna w tej formie, $\mathrm{z}$ niewielkimi odmianami, na 14 dokumentach książęcych redakcji paradyskiej, ibidem, t. 1, nr 245, 252, 278, 283, 285, 286, 335, 337, 338, 383 (dokument zaopatrzony został w 2 formuły pertynencyjne), 392, 397, 408 (dokument posiada 2 klauzule pertynencyjne oddane w identycznym kształcie).

${ }^{103}$ Por. powyżej szczegółową analizę dyktatu tychże odbiorców dokumentów książęcych.

${ }^{104}$ Zob. tak jak w przypisie nr 103.

${ }^{105}$ Zob. w literaturze przytoczonej w przypisie nr 16.
} 
edited according to common patterns. The proprietary clause in Greater Poland documents of the $12-13^{\text {th }} \mathrm{C}$. was present in Zbylut's document for the Cistercian monastery in Łekno. It could be found throughout the whole $13^{\text {th }}$ century. It seems that the author managed to show the permanent editorial patterns applied both in the ducal chancellery and on the document of recipients, first of all Cistercian monasteries i.e. Ląd, Paradyż, Obra, Owiński, or Ołobok. On the documents of centers experienced in chancellery practice, the proprietary clause enumerated generally arable lands and a detailed list appeared on the diplomas of the recipients with less practice in the use of the documents. According to the author one may say that the proprietary clause was a rhetorical figure - enumeratio - rather than an actual catalogue of arable lands.

\section{Bibliografia}

\section{Źródła drukowane}

Kodeks Dyplomatyczny Wielkopolski, t. 1-4, wyd. I. Zakrzewski, Poznań 1877-1881. Kodeks Dyplomatyczny Wielkopolski, t. 6, wyd. A. Gąsiorowski, H. Kowalewicz, Warszawa 1982

\section{Literatura}

Bielińska M., Kancelarie i dokumenty wielkopolskie XIII w., Wrocław 1967.

Borkowski O., Powstanie i rozwój opactwa cysterskiego w Paradyżu - Gościkowie w XIIXIV w., „Rocznik Lubuski”, t. 14, 1986, s. 177-212.

Fichtenau H., Forschungen über Urkundenformeln: ein Bericht, ,,Mitteilungen des Instituts für östrreichischer Geschichtsforschung”, t. 94, 1986, s. 285-339.

Fichtenau H. , Rhetorische Elemente in der ottonisch-salischen Herrscherurkunde, „, Mitteilungen des Instituts für österreichischer Geschichtsforschung", t. 68, 1960, s. 39-62.

Friese J., Pierwsza fundacja klasztoru cystersów w Przemęcie $z$ r. 1210, „Roczniki Historyczne", t. 14, 1938, s. 28-47.

Gąsiorowski A., Najdawniejsze dokumenty poznańskiego domu joannitów, „Studia Źródłoznawcze", t. 8, 1963, s. 83-95; t. 9, 1964, s. 47-59.

Gut A., Formularz dokumentów książąt zachodniopomorskich do połowy XIV wieku, Szczecin 2002. 
Gut A., Formuła pertynencyjna dokumentów książat zachodniopomorskich w XII i XIII wieku, [w:] Formuła, archetyp i konwencja w źródle historycznym, red. K. Skupieński, A. Górak, Lublin 2006, s. 83-98.

Hube R., Prawo polskie w wieku trzynastym, [w:] idem, Pisma zbiorowe, t. 2, Warszawa 1905.

Jurek T., Dokumenty fundacyjne opactwa w Ladzie, „Roczniki Historyczne”, t. 66, 200o, s. 7-53.

Kętrzyński S., Michał i Konrad, dwaj dyktatorzy kancelarii wielkopolskiej w połowie XIII w., [w:] Księga pamiątkowa ku czci O. Balzera, t. 1, Kraków 1925, s. 21-30.

Krasoń J., Uposażenie klasztoru cystersów w Obrze w wiekach średnich, Poznań 1950.

Krzyżanowski S., Dyplomy i kancelaria Przemysława II. Studium z dziejów dyplomatyki polskiej XIII w., „Pamiętnik Akademii Umiejętności, Wydział Historyczno-Filozoficzny", t. 8, 1890, s. 122-192.

Kuraś S., Przywileje prawa niemieckiego miast $i$ wsi małopolskich XIV-XV wieku, Wrocław 1971.

Likowski H., Najdawniejsze dzieje klasztoru cysterek w Ołoboku (1211-1292), „Sprawozdania Polskiej Akademii Umiejętności”, t. 26, 1921, s. 5-9.

Likowski H., Początki klasztoru cysterek w Owińskach (1242-1250), Poznań 1922.

Maleczyński K., Studia nad dyplomami i kancelarią Odonica i Laskonogiego 1202-1239, Lwów 1928.

Maleczyński K., Zarys dyplomatyki polskiej wieków średnich, cz. 1, Wrocław 1951.

Przybysz T., Fundacja i pierwotne uposażenie klasztoru cystersów w Łeknie, „,Rocznik Nadnotecki”, t. 7, 1976, s. 56-71.

Russocki S., Formy władania ziemia w prawie ziemskim Mazowsza (koniec XIV-połowa XVI wieku), Warszawa 1961.

Semkowicz W., Encyklopedia nauk pomocniczych historii, Kraków 1999.

Sikora F., Uwagi o dokumentach klasztoru cysterek w Owińskach, „Studia Źródłoznawcze”, t. 9, 1964, s. 61-73.

Sikora F., Janusz, kanclerz arcybiskupa Pełki i księcia Kazimierza Konradowica (1232-1252 i 1252/1253-1258), „Nasza Przeszłość”, t. 24, 1966, s. 87-125.

Sikora F., Krytyka autentyczności dokumentów Przemysława I, „Studia Historyczne”, t. 11, 1968, s. 139-179.

Sikora F., Przywileje rycerskie synów Władysława Odonica. Krytyka autentyczności, ,,Roczniki Historyczne", t. 34, 1968, s. 9-47.

Sikora F., Dokumenty i kancelarie Przemysła I oraz Bolesława Pobożnego 1239-1279 na tle współczesnej dyplomatyki wielkopolskiej, Wrocław 1969. 
Sikora F., Jeszcze o przywilejach rycerskich synów Odonica, „Studia Źródłoznawcze”, t. 16, 1971, s. 185-197.

Sikora F., Najstarsze dokumenty i dzieje klasztoru bożogrobców w Gnieźnie, „Studia Źródłoznawcze", t. 19, 1974, s. 47-74.

Szymański J., Nauki pomocnicze historii, Warszawa 2001.

Vocabulaire international de la diplomatique, ed. Ma Milagros Carcel Orti, Valencia 1994.

Waraczewski H., Proces fundacyjny klasztoru cystersów w Lądzie nad Warta, , Nasza Przeszłość”, t. 83, 1994, s. 151-168.

Wyrwa M., Procesy fundacyjne klasztorów cysterskich linii altenberskiej, Łekno-Ląd-Obra, Poznań 1995. 